\title{
Determinants of Household Savings in South Africa: An Econometric Approach (1990-2011)
}

\author{
Chipote Precious \\ Tsegaye Asrat \\ University of Fort Hare (Department of Economics), East London Campus \\ 50 Church Street, Private Bag X 9083, East London, 5200, South Africa
}

\section{Doi:10.5901/mjss.2014.v5n15p183}

\begin{abstract}
This paper examines the determinants of household savings in South Africa over the period 1990-2011. Based on the life cycle hypothesis upon which the study is based as well as empirical literature, particular attention is paid to the effects of age dependency ratio, the level of household income, inflation and real interest rate on household savings. The study employs the Augmented Dickey-Fuller and Phillips Perron unit root tests to test for stationarity in the time series. The Johansen cointegration and the Error Correction Mechanism are employed to identify the long-run and short-run dynamics among the variables. The results of the study reveal that contrary to a theoretical expectation, the level of income and household savings are negatively related, implying that South African households do not only save but increasingly rely on debt to finance their spending. On the other hand age dependency ratio, inflation and real interest rate have positive long run relationships with household savings rate. The study recommends that the government should embark on counter-cyclical fiscal policy to avoid the development of excessive current account deficits during periods of more rapid economic growth, rising investment and falling saving.
\end{abstract}

Keywords: Household savings, Life cycle hypothesis, Vector Error Correction Model, South Africa

\section{Introduction}

The pivotal role played by savings in enhancing a sustainable economic growth through its effect on investment has attracted much attention in the academic and policy discourse. Domestic savings that are generated in the economy provide the means for the financing of domestic fixed capital formation, which, in turn, affects economic growth potential. Savings cushion the economy against fluctuating international capital. In periods of low or fluctuating capital, domestic savings are essential to finance high levels of capital formation thereby leading to increased productivity and sustainable economic growth. In addition, higher national saving would help to reduce, rather than exacerbate, the trade and current account deficits. Without a higher rate of national saving, the country will be faced with one of two possible outcomes: either the current account deficit will remain high, running the risk of fueling increased protectionist pressures; or fail to maximize investment in the domestic economy precisely when the return to such investment is high (Luüs, 2005).

Domestic savings consist of three components: corporate, household and government savings. In South Africa household savings are relatively low by international standards. According to the Development Bank of Southern Africa (2011), which makes reference to a recent World Bank economic update on South Africa, it is argued that the primary driver behind low savings is a low household savings rate driven by the country's exceptionally high unemployment rate. This is confirmed by Masilela (2012) in pointing out that while government and corporates are saving, individual South Africans are not and the trend appears to be getting worse each year. This makes the economy to rely on foreign capital inflows to finance domestic investments thereby making the economy to be vulnerable to external shocks.

This paper aims to achieve a better understanding of what drives aggregate household savings, based on a detailed empirical analysis for which we estimate a long run savings function. The rest of the paper is outlined as followssection two presents an overview of household savings in South Africa from 1990 to 2011, section three reviews various related literatures, section four discusses the methodology, section five presents the data analysis and interpretation of findings and section six provides conclusion, and recommendations. 


\section{An Overview of Household Savings in South Africa}

Figure 1 illustrates the trends in net household savings in South Africa from 1990 to 2011.

Figure 2.7: Net household savings as a \% of GDP

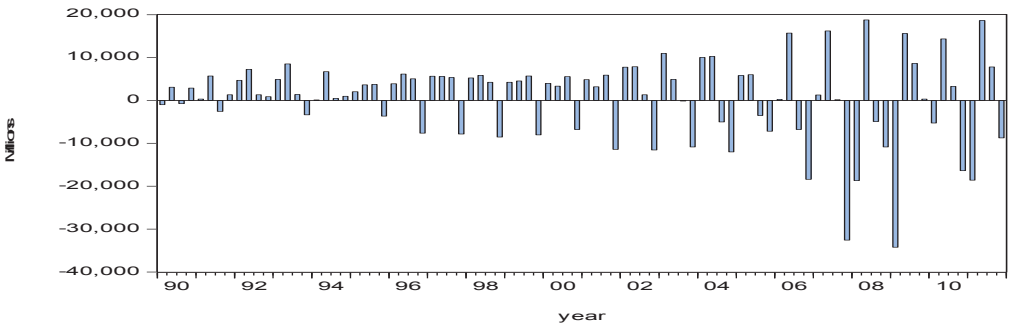

Source: South Africa Reserve Bank (2012)

According to South African Reserve Bank (2012), net household savings as a percentage of GDP averaged 1.63\% in the 1990s and between 2000 and 2005, it decreased significantly to an average of $0.35 \%$. Between the years 2006 and 2008 , net household savings as a percentage of GDP further decreased to an average of $-0.63 \%$ before slightly increasing to an average of $-0.20 \%$ for the period $2009-2011$.

Several reasons have been put forward as the likely reasons for low household saving levels in the 1990s. Slow economic growth and rising tax and real interest burdens which all reduce per capita income contributed to the decline in the saving rate in the 1990s (Mnyande, 2010). In addition, the effects of financial liberalisation aided strongly to the significant rise in the consumption-to-income ratio as well as reducing credit constraints, thereby reducing household savings (Aron and Muellbauer, 2001).

Although in the period 1998 to 2005 household saving levels were high, the frequency of dissavings was also high. Romm (2005) explain that expanding household wealth as a result of rising asset values, particularly house prices and the decline in the interest rate from 1998 augmented the effects of financial liberalisation on declining household saving. Klein (n.d) in Manyama (2007) explains that in 2002, the South African government was criticized for not creating a favorable savings environment as economists argued that the government is skewing the taxes against top earners, henceforth reduced household savings since the largest portion of household savings in South Africa is contributed by high-income earners.

The period 2006 to 2011 was characterized by high levels of dissavings and low frequency of dissavings. The negative effects of the global economic crisis of 2008 may be the likely reason behind high dissavings especially from the end of 2007 to the start of 2009. Improved incomes after the 2008 crisis coupled with the iintroduction of the National Credit Act (NCA) in June 2007 whose aim is to prevent reckless spending helped boost savings after 2009.

\section{Literature Review}

Due to the crucial role played by savings in promoting a sustainable economic growth, many economists explored the subject of explaining the determinants of savings. There is a vast literature on the macroeconomic determinants of household saving behaviour both on an individual country-basis as well as across nations. Most of these studies use the life cycle hypothesis $(\mathrm{LCH})$ in explaining the major determinants of household savings. Formulated by Modigliani and Brumbergin (1954), the general LCH has been modified over the years to overcome its shortfalls. The hypothesis is based on the notion of a rational consumer who tries to maximize utility subject to a budget constraint. It assumes a finite lifetime with a distinct period of retirement at the end. The LCH stresses the role played by savings in smoothing out consumption over the entire life of an individual. In its simplest form, life cycle hypothesis divides the lifetime of individuals into a working period and a retirement period (Crown, 2002). In this way, the structure of the model clearly explains the vital role played by demographic factors (age) and income growth in explaining saving patterns.

The LCH proposes a hump-shaped savings pattern whereby the early and later stages of life are associated with dissavings and the middle stage is characterized by savings. It is argued that the young and old generations are less productive and have no or less income henceforth they tend to dissave. On the other hand the middle generation is more 
productive and has more income to save for the future. The hypothesis also point out the crucial role played by income growth in explaining savings behaviour arguing that an increase in the rate of growth of income per capita increases the aggregate saving rate (Nwachukwun and Egwaikhide, 2007).

Huang (2006) explains that in 1986 Modigliani extended the basic life cycle model by including two more influences on household saving; the real interest rate and social security payments. There is lack of consensus on the likely effects of real interest rate on savings due to the contradicting substitution and income effects. Whilst the substitution effect describes that an increase in interest rate will increase savings as a consumer forgoes current consumption for more future returns, the income effect is for the idea that an increase in interest rate will lead to reduced savings as consumers will be expecting increased incomes in the future. Studies such as Callen and Thimman (1997); Dirschmid and Glatzer (2004) as well as Athukorala and Tsai (2010) support the substitution effect whilst Loayaza et al (2000); Aron and Mullerberg (2000) and Simleit et al (2011) support the income effect. Some studies for example Schmidt-Hebbel et al (1992) and Chen (2002) however find no relationship between savings and interest rate altogether.

The LCH stresses that the existence of social security payments negatively impacts on savings the precautionary motive for saving is reduced. Several studies such as Jappelli (2005) support this proposal.

Harris, Loundes and Webster (1999) used a unique survey of consumers to examine the determinants of household savings in Australia. The data used in the estimation were driven from the pooled results of quarterly surveys conducted over the period August 1994 to February 1999. Results of the study support the observation that incomes are the most important determinants of household saving. Demographics and householders level of economic optimisms were also found to be contributing much towards household savings.

Findings of the study done by Kulikovet al (2007) to ascertain the determinants of household saving in Estonia reveal that income and wealth related covariates together with other important variables, such as possession of durable goods and educational attainment were found to be among the most important determinants of household saving behavior.

Fasoranti (2007) focused on the influence of rural saving in mobilization on economic development of rural dwellers in Nigeria. Data was collected through a questionnaire to 100 respondents from 5 villages. Results of the Ordinary Least Square estimation technique indicate that income, human capital, investment and assets positively contribute to total savings. The rural saving situation in Vietnam was examined by Newman et al (2008) focusing on the determinants of household savings with special interest in the possible effects of network savings behaviour on household savings behaviour. Data used was taken from the Vietnam Access to Resources Households Survey implemented between August and September 2006 in 12 provinces. Among the general determinants of savings discovered, it was noted that wealth dominates the participation decision, no significant effect of education was found, negative effects of age of household head were found and financial savings were low and share of formal savings were relatively small.

The determinants of aggregate household savings in a panel of 18 developed countries for the period 1980-2005 were investigated by Salotti (2008) giving much focus to the role played by wealth. Results of the fully modified ordinary least square (FMOLS) estimation technique indicate that an increase in wealth negatively affects household savings.

Du Plessis (2008) investigated the determinants of household saving behaviour in South Africa by conducting oneon-one interviews with the selected economists, so as to gauge each participant's opinion. Although most interviewees agreed to the idea that theoretical determinants of savings discussed in saving literature play a key role in determining household savings, they however did not regard current income as the primary determinant of savings behaviour. Overall, major findings of the study show that household saving is impacted negatively by the prevalence of an aspirational culture in which consumption is encouraged by access to credit facilitated by South Africa's sophisticated financial sector. More so, governmental policies with regard to wealth distribution and welfare payments are regarded to contribute to the creation of a culture of dependence and a reduction in household savings.

Mahlo (2011) estimated the relationship between household savings and income, consumption, interest rate and debt in South Africa using the ordinary least squares estimation model over the period 1990-2009. His results point out that whilst there is a positive relationship between income and household saving as well as between household savings and interest rates; a negative significant relationship exists between household consumption and household savings plus between household debt and savings. Overall, he notes that household income is the main determinant of household savings in South Africa.

From the reviewed literature variables such as interest rate, income, inflation rate and demographic factors tend to be central to the analysis of factors that determines household savings. The study will consider these variables based on their relevance to South Africa and availability of data. Literature is inconclusive on the likely effects of different variables on household savings. 


\section{Methodology}

The study adopts an econometric model in explaining the determinants of household savings in South Africa. The existence of a short run and long equilibrium relationship among variables is established by employing various econometrics techniques. These include the Augmented Dickey-Fuller (ADF) and Phillips Perron Unit Root tests, Johansen Co-integration test and the Vector Error Correction Mechanism (VECM).

\subsection{Model Specification and Definition of Variables}

In this study based on the review of the literature, the the household savings will be modeled as a function of the level of real disposable income (Y), age dependency Ratio (ADR), real interest rate (RIR) and inflation (INF). The household savings model can therefore be specified as follows:

$H S R=f(Y, A D R, R I R, I N F)$.

Where:

$H R S$ is the ratio of household savings to household disposable income.

$Y$ is the level of annual household disposable income. GDP per capita is used in the study to measure the level of household disposable income.

$A D R$ is the age dependency ratio. Age dependency ratio in this context is defined as the ratio of dependents (people younger than 15 or older than 64) to the working-age population (those ages 15-64). Data used in this study is shown as the proportion of dependents per 100 working-age population.

$R I R$ is the real interest rate. In this study real interest rate is defined as the lending interest rate adjusted for inflation as measured by the GDP deflator.

INFis inflation as measured by the consumer price index (CPI) excluding food and non-alcoholic beverages for all urban areas. The CPI price index reflects the annual percentage change in the cost to the average consumer of acquiring a basket of goods and services that may be fixed or changed at specified intervals, such as yearly.

The econometric form of equation (1) above is represented as:

$H R S=\beta_{0}+\beta_{1} Y_{t}+\beta_{2} A D R_{t}+\beta_{3} R I R_{t}+\beta_{4} I N F_{t}+\varepsilon_{t}$

Where:

$\beta_{0}=$ Intercept of relationship in the model/constant

$B_{1}-\beta_{4}=$ Coefficients of each independent or explanatory variable

$\varepsilon_{t}=$ Error term

Real household disposable income will be converted into logarithm in order to obtain elasticity coefficient and remove the effect of outliers. Thus the function becomes:

The 'priori' expectations are determined literature and refer to the expected relationship between the explained variable and the explanatory variable(s). Income and inflation are anticipated to have positive coefficients signs whereas age dependency ratio is expected to have a negative coefficient. Real interest can have either a positive or a negative coefficient.

\subsection{Data Sources}

The study gathered time series annual data for the above variables for the period covering 1990 to 2011 from the World Bank Statistic and the Reserve Bank of South Africa Statistics. Due to the unavailability of ratio of savings to GDP data which is the most suitable time series, this study used the ratio of savings to household disposable income is considered. Nevertheless ratio to disposable income is a good measure since individuals save out of disposable income.

\section{Data Analysis and Interpretation of Findings}

\subsection{Unit Root Test}

Since this study involves time series data, the Johansen technique cannot be applied unless it is established that the variables concerned are stationary. This study uses the Augmented Dickey-Fuller (ADF) and Phillip-Perron (PP) unit root tests to check the stationarity of the variables and test results are presented in Table 1. Data is tested for stationarity so as to avoid the problem of spurious regression. Both ADF and PP tests test the null hypothesis of a unit root. The null hypothesis of a unit root is rejected in favour of the stationary alternative in each case if the test statistic is more negative than the critical value. 
Table 1: Unit root tests 1990Q1- 20011Q4 at levels and first differences $(\Delta)$

\begin{tabular}{|c|c|c|c|c|c|}
\hline & HSR & ADR & LY & INF & RIR \\
\hline \multicolumn{7}{|c|}{ ADF } \\
\hline Level & -2.315570 & -1.047577 & -2.907188 & -2.916467 & -2.601229 \\
\hline First Difference & $-8.260285^{\star \star \star}$ & -2.525294 & $-3.715790^{\star \star}$ & $-3.516864^{\star \star}$ & $-3.169631^{\star}$ \\
\hline \multicolumn{7}{|c|}{ PP } \\
\hline Level & $-6.982248^{\star \star \star}$ & 0.496182 & -2.913500 & -2.125038 & -1.900078 \\
\hline First Difference & $-13.44157^{\star \star \star}$ & $-5.514999^{\star \star \star}$ & $-3.747675^{\star \star}$ & $-5.002962^{\star \star \star}$ & $-4.806597^{\star \star \star}$ \\
\hline
\end{tabular}

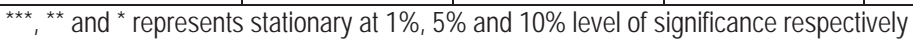

Results of unit root tests reported in Table 1 above indicate that when using the ADF test, variables are not stationary at level series but however become stationary when differenced once except for the variable ADR which is not stationary after the first difference. When the PP test is considered, variables become stationary when differenced once apart from the variable HSR which is stationary at level series. Based upon the results of the much stricter PP test, this study therefore concludes that all the variables are integrated of order 0 and 1.

\subsection{Co integration Analysis Result and Interpretation}

Having established the order of integration, co-integration tests are conducted to establish the existence of a long-run equilibrium relationship amongst the variables. In determining the number of co-integrating vectors, the study applied trace test and maximum eigenvalue test using the more recent critical values of MacKinnon et al. (1999). The assumption of intercept and trend was used for all the variables as indicated by the Pantula Principle test results presented in Table 2 below.

Table 2: The Pantula principle test results

\begin{tabular}{|c|c|c|c|c|c|c|c|}
\hline R & n-r & \multicolumn{2}{|c|}{ Model 2 } & \multicolumn{2}{c|}{ Model 3 } & \multicolumn{2}{c|}{ Model 4 } \\
\hline & & Trace Test statistic & Critical value & Trace Test statistic & Critical value & Trace Test statistic & Critical value \\
\hline 0 & 3 & 90.43161 & 76.97277 & 81.68163 & 69.81889 & 92.83373 & 88.80380 \\
\hline 1 & 2 & 58.89628 & 54.07904 & 50.14968 & 47.85613 & $\mathbf{5 9 . 8 4 0 8 5}$ & 63.87610 \\
\hline
\end{tabular}

Note: * indicates the first time that the null cannot be rejected

Table 3 below presents the results for both trace test and maximum eigenvalue for unrestricted co-integration rank test. The trace statistic tests the null hypothesis of $r$ co-integrating vectors against the alternative hypothesis of $n$ co-integrating relations. Results from the much stricter Johansen co-integration trace test indicate that there is 1 co-integrating relationship at $5 \%$ level of significance. The null hypothesis of no co-integrating vectors is rejected since the test statistic of about 92.83373 is greater than the $5 \%$ critical value of approximately 88.80380 . However the maximum eigenvalue test fails to reject the null hypothesis of no co-integration as the test statistic of about 32.99288 is less than the $5 \%$ critical value of about 38.3310. Consequently, the maximum eigenvalue test proposes that there is no co-integrating relationship in the household savings model. Therefore based upon the results of the much stricter Johansen co-integration trace test, this study concludes that there exists 1 co-integrating relationship.

Table 3: Johansen-Juselius Co-integration Test Results

\begin{tabular}{|c|c|c|c|c|c|c|c|}
\hline $\begin{array}{c}\text { Hypothesized } \\
\text { No. of CE(s) }\end{array}$ & Eigenvalue & $\begin{array}{c}\text { Trace } \\
\text { Statistic }\end{array}$ & $\begin{array}{c}0.05 \\
\text { Critical Value }\end{array}$ & Prob** & $\begin{array}{c}\text { Max- Eigen } \\
\text { Statistics }\end{array}$ & $\begin{array}{c}0.05 \\
\text { Critical Value }\end{array}$ & Prob $^{\star *}$ \\
\hline None $^{\star}$ & 0.321690 & 92.83373 & 88.80380 & 0.0248 & 32.99288 & 38.33101 & 0.1808 \\
\hline At most 1 & 0.213853 & 59.84085 & 63.87610 & 0.1043 & 20.45193 & 32.11832 & 0.6161 \\
\hline At most 2 & 0.182739 & 39.38892 & 42.91525 & 0.1078 & 17.15277 & 25.82321 & 0.4450 \\
\hline At most 3 & 0.136838 & 22.23616 & 25.87211 & 0.1328 & 12.50798 & 19.38704 & 0.3693 \\
\hline At most 4 & 0.108143 & 9.728181 & 12.51798 & 0.1401 & 9.728181 & 12.51798 & 0.1401 \\
\hline
\end{tabular}

Trace test indicates 1 co-integrating eqn(s) at the 0.05 level; Max-eigenvalue test indicates no co-integration at the 0.05 level; * denotes rejection of the hypothesis at the 0.05 level 


\subsection{Vector Error Correction Model (VECM)}

A vector error correction model (VECM) is used to disaggregate the short or long run effects. Table 4 below presents the results of the long-run relationships. From the results, the long run co-integrating equation (3) will be as follows:

$H S R_{t}=-5.8235-180.7911 Y_{t}+1.0473 A D R_{t}+2.0904 R I R_{t}+6.3710 / N F_{t}+\varepsilon t_{1}$.

Considering crucially at the numerical values of the coefficients and their respective signs, Equation (3) is interpreted as indicating that if all independent variables are held constant, HSR will reduce by 5.8235 units in the long run.

Table 4: Vector Error Correction Model- Long-run relationships

Dependent: HSR

\begin{tabular}{|c|c|c|c|}
\hline Variable & Coefficient & Standard error & t-statistic \\
\hline Constant & 1693.719 & - & - \\
\hline HSR(-1) & 1.000000 & - & - \\
\hline ADR(-1) & 1.047344 & 1.93267 & 0.54191 \\
\hline Y(-1) & -180.7911 & 109.988 & -1.64373 \\
\hline INF(-1) & 6.370956 & 1.17913 & 5.40310 \\
\hline RIR(-1) & 2.090401 & 0.79107 & 2.64250 \\
\hline
\end{tabular}

A positive co-integrating equation coefficient of ADR 1.047344 signifies a positive and insignificant relationship between HSR and ADR whereby a unit increase in ADR will cause HSR to increase by 1.047344 units. This relationship does not concur with the theory as well as expected priori. Findings of the study support the work of Hermansson (2002) who argue against the saving pattern proposed by the LCH stating that research of actual saving in several countries show that there is more saving and lower borrowing than expected among young people despite the fact that current income is less than future income. In addition, some economists argue that the older generations save for bequest motives, thereby supporting the positive relationship. Findings also support the works of Aktas et al (2012); Bersales and Mapa (2006), and Rehman et al (2010).

A negative co-integrating equation coefficient for $\mathrm{Y}$ of about 180.7911 represents a negative relationship that exists between the level of income and household savings, whereby a unit increase in Y causes HSR to decrease by 180.7911 units. This is also inconsistent with theory and expected priori. The findings of the study can be attributed to lack of selfcontrol as argued by many theorists that individuals lack self-control such that if income increases in some periods, households might increase consumption levels and fail to increase savings. Mahlo (2011) discuses that lack of selfcontrol which hinders household savings can distort the behaviour of savings as predicted by theory as some situations are more conducive to savings than others, at ceteris paribus. In the South African context, Simleit, Keeton and Botha (2011) as well as Linde (2011) also found that income and household savings are negatively related. Prinsloo (2000) further supports this by proposing that household savings behave counter-cyclical in South Africa. This means that households tend to increase their levels of saving when the economy is in a downswing and decrease saving levels during an upswing. One such reason for such a saving behaviour may be that during downswing households expect the fall in economic activity to continue and thus the need to save more for future use. Likewise, during an upswing household expect the favorable economic activity to last for a longer period hence reduced saving levels as less income will be required for future consumption.

The positive coefficient for INF of approximately 6.370956 indicates that inflation has a strongly positive impact on household savings. It can be deduced that in the long run, if inflation rate should increase by a unit; it will cause household savings to increase by approximately 6.371 units. Findings support the works of Loayza, Schmidt-Hebbel and Servén (1999); Hüfner and Koske (2010) and Guan (2011.

The impact of real interest rate on household savings is theoretically ambiguous; it can either be positive or negative depending on the effect (substitution or income) at hand. Results of the study indicate a positive coefficient signifying positive relationship whereby a unit increase in RIR will lead to an increase in HSR by 2.090 units. In the South African context, although Aron and Mullerberg (2000) as well as Simleit et al (2011) found a negative relationship, Mahlo (2011) discovered a positive relationship. 


\subsection{Short-Run Analysis: An Error-Correction Model}

The purpose of the short run analysis is to discover whether the short-run dynamics are influenced by the estimated longrun equilibrium conditions, that is, the co-integrating vectors. The error correction mechanism is the speed or degree of adjustment i.e. the rate at which the dependent variable adjust to changes in the independent variables. The negative coefficient of the Error Correction Mechanism implies that there is a feedback mechanism in the short run. The error correction helps to correct any disequilibrium in the short run. Positive coefficient indicates that any disequilibrium in the variable continues to grow. However it should be noted that a positive coefficient in an error correction model could also signify incomplete specifications. Table 5 below show the results of the short run vector error correction model.

As reported in table 5 , the coefficient of D (HSR) of approximately 0.003274 indicates that the speed of adjustment is around $0.33 \%$. This implies that if there is a deviation from equilibrium, only $0.33 \%$ is corrected in one quarter as the variable moves towards restoring equilibrium. This means that there is slow speed of adjustment of HSR which maybe reflect little pressure on the variable in restoring to the equilibrium in the long run due to any disturbance. The slow speed of adjustment of GDP maybe interpreted as that there are other variables other than the ones specified in the model that affects HSR. The speed of adjustment is however not statistically significant with a t-value of around 0.27705

Table 5 : Vector Error Correction Model- Short-run relationships

\begin{tabular}{|c|c|c|c|}
\hline Variable & Coefficient & Standard error & t-statistic \\
\hline Constant & 1693.719 & - & - \\
\hline$D(H S R)$ & -0.003274 & 0.01182 & -0.27705 \\
\hline$D(A D R)$ & 0.001684 & 0.00218 & 0.77328 \\
\hline$D(L Y)$ & -0.000178 & $4.8 E-05$ & -3.67048 \\
\hline$D(I N F)$ & -0.037088 & 0.00888 & -4.17700 \\
\hline$D(R I R)$ & -0.017455 & 0.00850 & -2.05277 \\
\hline
\end{tabular}

\subsection{Diagnostic checks for the VECMs}

The diagnostic checks are very important to the model because they validate the parameter evaluation outcomes achieved by the estimated model. This arises because, if there is a problem in the residuals from the estimated model; it is an indication that the model is not efficient such that parameter estimates from the model may be biased. The VAR was tested for serial correlation using the langrage multiplier (LM) test, heteroskedesticity using the White test and normality by employing the Jarque-Bera. Table 6 presents the diagnostic tests results and they all reveal the suitability of the model hence the results from this research can be relied on.

Table 6: Diagnostics test results

\begin{tabular}{|l|l|c|c|}
\hline Test & Null hypothesis & t-statistic & Probability \\
\hline Langrage Mulitiplier (LM) & No serial correlation & 12.19147 & 0.9850 \\
\hline Jarque- Bera (JB) & There is a normal distribution & 330 & 0.9700 \\
\hline White (CH-sq) & No conditional heteroskedesticity & 330 & 0.9700 \\
\hline
\end{tabular}

\section{Conclusion and Recommendations}

From the literature, savings plays a crucial role in an economy. They enhance a sustainable economic growth through financing domestic fixed capital formation. Savings act as a buffer in periods of low and/or fluctuating international capital flows. The focus of the study has been to examine the determinants of household savings in South Africa over the period 1990-2011. The study employed the Johansen co-integration test and Error Correction Method. The co-integration test showed the existence of long run equilibrium relationship among the variables. Findings of the study showed that whilst there is a negative relationship between household savings and the level of income, positive relationships exists between household savings and age dependency ratio, inflation and real interest rate. Findings of the study again indicated that all the variables under study except for the age dependency ratio are significant in explaining changes in household savings.

Based on the findings in the study, a number of recommendations may be made. Firstly, the government should embark on counter-cyclical fiscal policy to avoid the development of excessive current account deficits during periods of 
more rapid economic growth, rising investment and falling saving. The government should increase its savings through an improvement in the government budget balance so as to raise overall savings in periods of economic upswings. Secondly the government should look for alternative ways such as borrowing and attracting foreign domestic investments (FDI) to fund domestic investments in periods of economic upswings as household savings will be low.

\section{References}

Aktas, A., Guner, D., Gursel, S. and Uysal, G. 2012. Structural Determinants of Household Savings in Turkey: 2003-2008. Bahcesehir University. Betam Working Paper Series \# 007

Aron, J and Muellbauer, J. 2000. Personal and Corporate Saving in South Africa. University of Oxford, England

Athukorala, P. C. and Tsai, P. L. 2003. Determinants of Household Saving in Taiwan: Growth, Demography and Public Policy. Journal of Development Studies Volume 39 (5).

Bersales, L. G S. and Mapa, D. S. 2006. Determinants of Household Saving in the Philippines. University of the Philippines

Callen, T. and Thimann, C. 1997. Empirical Determinants of Household Saving: Evidence from OECD Countries. Working Paper of International Monetary Fund WP/97/181.

Chen, C. 2002. Interest rates, savings and income in the Chinese economy. Journal of Economic Studies, Vol 29, No1: 59-73.

Crown, W. H. 2002. Life Cycle Theories of Savings and Consumption. Encyclopedia of Aging. [Online]. Available: http[Accessed 9 May. 2012].

Development Bank of Southern Africa. 2011. Prospects for South Africa's future. Development Planning Division. [Online]. Available: http://www.dbsa.org/EJournal/Documents/DBSA\%20\%Development\%20\%Report\%202011.pdf. [Accessed 25 April 2012].

Dirschmind, W. and Glatzer, E. 2004. Determinants of the household saving rate in Austria. The Journal of Monetary Policy \& the Economy25-38 [Online]. Available: http://www.oenb.at/en/img/mop_2004_4_analyses2_tcm16-23739.pdf. [Accessed5 April 2012]

Du Plessis, G. 2008. An exploration of the determinants of South Africa's personal saving rate- Why do South African households save so little? Master's thesis, University of Pretoria.

Guan, W. 2011. Saving Europe: Determinants of Household Savings. Columbia Economics Review

Harris, M. N., Loundes, J. and Webster, E. 2002. Determinants of Household Saving in Australia. Economic Record, 78: 207-223

Haque, N. U., Pesharan M. H. and Sharma, S. 1999. Neglected heterogeneity and dynamics in cross country savings regressions. IMF Working Papers, No. 99/128.

Hermansson, C. 2002. The Outlook for Students from a Life Cycle Perspective. Economic Research Department Discussion Paper No. 3

Huang, P. 2006. Determinants of Household Savings in China. Lincoln University

Hüfner, F. and Koske, I. 2010. Explaining Household Saving Rates in G7 Countries: Implications for Germany. OECD Economics Department Working Papers, No. 754

Jappelli, T. 2005. The Life-Cycle Hypothesis, Fiscal Policy, and Social Security. Centre for Studies in Economics and Finance Working Paper No. 140

Kulikov, D., Paabut, A. and Staehr, K. 2007. A Micro econometric analysis of household saving in Estonia: Income, wealth and financial exposure. Working Paper Series 8/2007 Estonian National Bank.

Linde, K. L. 2011. An analysis of the determinants and recent decline of private savings in South Africa. Rhodes University Grahamstown

Loayza, N., Schmidt-Hebbel, K. and Serven, L. 2000. What drives private saving across the world? Review of Economics and Statistics, $82(2), 165-81$

Luüs, C. 2005. Household saving behaviour and its promotion in South Africa. South African Institute of Financial Markets.

Mahlo. N. 2011. Determinants of household savings in South Africa. University of Johannesburg.

Masilela, E. 2012. Savings for the Culture. South African Savings Institute.

Manyama, M. M. 2007. Instilling a culture of saving in South Africa. University of Pretoria.

Mnyande, M. 2010. The role of monetary policy in influencing savings behaviour in the South African economy. South African Reserve Bank

Newman, C., Tarp, F., Van DEN Broeck, K., Quang, C. T. and Khai, L. D. 2008. Household savings in Vietman: Insights from a 2006 rural household survey. Vietnam Economic Management Review, Vol 3, No 1

Nwachukwu, T. E. And Egwaikhide, F. O. 2007. An Error-Correction Model of the Determinants of Private Saving in Nigeria. University of Ibadan, Nigeria.

Prinsloo, J. W. 2000. The saving behaviour of the South African economy. South African Reserve Bank Occasional Paper No. 14

Rehman, H., Faridi. M. Z. And Bashir, F. 2010. Households Saving Behaviour in Pakistan: A Case of Multan District. Pakistan Journal of Social Sciences (PJSS) Vol. 30, No. 1 (September 2010), pp. 17-29

Romm, A. T. 2003. The relationship between savings and growth in South Africa: An empirical study. University of the Witwatersrand

Salotti, S. 2008. Global imbalances and household savings: the role of wealth. Munich Personal RePEc Archive. [Online]. Available: http://mpra.ub.uni muenchen.de/17729/ MPRA Paper No. 17729 . [Accessed 2 August 2012]

Schmidt-Hebbel, K., Webb, S. B. \& Corsetti, G. 1992. Household Saving in Developing Countries: First Cross-Country Evidence. The World Bank Economic Review, Vol 6. No 3 529-547

Simleit, C., Keeton, G. And Botha, F. 2011. The determinants of household savings in South Africa. Rhodes University, South Africa. J. Stud. Econ. Econometrics, 2011, 35(3)

South African Reserve Bank. 2012. Quarterly Bulletin, June 2012. No. 264. 